\title{
Tidally-generated internal waves in Southeast Hudson Bay
}

\author{
Vladislav Y. Petrusevich, ${ }^{\mathrm{a}, *}$, Igor A. Dmitrenko ${ }^{\mathrm{a}}$, Igor E. Kozlov ${ }^{\mathrm{b}, \mathrm{c}}$, Sergey A. Kirillov ${ }^{\mathrm{a}}$, \\ Zou Zou A. Kuzyk ${ }^{\mathrm{a}}$, Alexander S. Komarov ${ }^{\mathrm{d}}$, Joel P. Heath ${ }^{\mathrm{e}}$, David G. Barber ${ }^{\mathrm{a}}$, Jens K. Ehn ${ }^{\mathrm{a}}$ \\ ${ }^{\text {a } C e n t r e ~ f o r ~ E a r t h ~ O b s e r v a t i o n ~ S c i e n c e, ~ U n i v e r s i t y ~ o f ~ M a n i t o b a, ~} 467$ Wallace Building, 125 Dysart Road, Winnipeg, Manitoba, Canada, MB R3T 2N2, \\ ${ }^{\mathrm{b}}$ Satellite Oceanography Laboratory, Russian State Hydrometeorological University, Saint-Petersburg, Russia \\ ${ }^{\mathrm{c}}$ Remote Sensing Department, Marine Hydrophysical Institute of RAS, Sevastopol, Russia \\ d Data Assimilation and Satellite Meteorology Research Section, Environment and Climate Change Canada, Ottawa, Ontario, Canada \\ e Arctic Eider Society, St. John's, Newfoundland, Canada
}

\section{A R T I C L E I N F O}

\section{Keywords:}

Internal waves

Semidiurnal tides, tidal analysis

Freshwater discharge

Water dynamics

Land-fast sea ice

Remote sensing

SAR imaging

Hudson Bay

Arctic Ocean

\begin{abstract}
A B S T R A C T
The location of the amphidromic point of the M2 tide in Hudson Bay roughly coincides with Belcher Islands, a region where the surface mixed layer stays relatively fresh throughout summer and winter due to significant ice melt and river discharge. High-resolution satellite radar imagery for the ice-free season revealed that the coastal region in the south-east Belcher Islands is a hot spot for short-period internal wave activity. For a first investigation of tidal dynamics in the region, we took advantage of the sea ice platform to deploy an ice-tethered mooring consisting of nine conductivity and temperature sensors and an acoustic Doppler current profiler. The mooring was deployed at $65 \mathrm{~m}$ depth in January-March 2014 in a narrow channel between Broomfield and $\mathrm{O}^{\prime}$ Leary islands located in the south-east tip of the Belcher Islands group in Hudson Bay $\left(56^{\circ} 20^{\prime} \mathrm{N}, 79^{\circ} 30^{\prime} \mathrm{W}\right)$, northeast Canada. The surface mixed layer under the land-fast ice in this area stays relatively fresh through winter presumably because of significant winter river discharge in nearby James Bay. The mooring recorded oscillations of temperature and salinity throughout the whole water column, which were attributed to vertical displacement caused by internal tidal waves. The tidal harmonic analysis performed for the $\mathrm{M}_{2}$ tidal constituent showed the dominance of the baroclinic tide with maximum velocity amplitudes at the surface and decreasing with depth. Vertical displacements of water parcels derived from both temperature and salinity were statistically similar and displayed the maximum values of $11.9 \mathrm{~m}$ at $35 \mathrm{~m}$ (instrument depth). The combination of winter hydrographic data and summer satellite observations confirmed that the observed internal waves were generated by the interaction of strong tides, typical for Hudson Bay, with highly variable bottom topography southeast of the Belcher Islands archipelago.
\end{abstract}

\section{Introduction}

Internal waves in Arctic regions have been of recent scientific interest due to their role in vertical mixing, and their influence on the heat budget of the upper ocean and ice cover (Morozov and Pisarev, 2002; Garrett and Kunze, 2007; Morozov et al., 2008, 2017; Guthrie et al., 2013; Rippeth et al., 2017). Several studies of internal waves were conducted in Arctic fjords during ice-free (Svendsen et al., 2002; Støylen and Fer, 2014) and ice covered (Parsmar and Stigebrandt, 1997; Marchenko et al., 2010; Støylen and Weber, 2010; Morozov and Marchenko, 2012) periods. During ice-free periods, internal waves in fjords are forced by changing winds and barotropic tides (Svendsen et al., 2002). During the ice-covered season, internal waves are formed through the interaction between the barotropic tide, bottom topography and the background stratification (Støylen and Weber, 2010; Luneva et al., 2015). In certain cases, the ice cover can act as a contributing factor towards internal tidal wave amplification (Dmitrenko et al., 2002, 2012). Internal waves can be generated below the land-fast ice due to the interaction of the tidal flow and glacier outlets (Kirillov et al., 2017).

Hudson Bay (Fig. 1) is a large $\left(\sim 831,000 \mathrm{~km}^{2}\right)$, seasonally-ice covered shelf sea, connected to the Arctic Ocean through the Canadian Archipelago and to the North Atlantic through Hudson Strait. Hudson Bay receives freshwater inputs from the largest watershed in Canada, which, together with sea ice-melt, results in strong seasonal stratification (cf., Ferland et al., 2011). The tide in Hudson Bay is mostly lunar semidiurnal $\left(\mathrm{M}_{2}\right)$ with an amplitude of about $3 \mathrm{~m}$ at the entrance to Hudson Bay from Hudson Strait (Prinsenberg and Freeman, 1986;

\footnotetext{
* Corresponding author.

E-mail address: vlad.petrusevich@umanitoba.ca (V.Y. Petrusevich).
} 


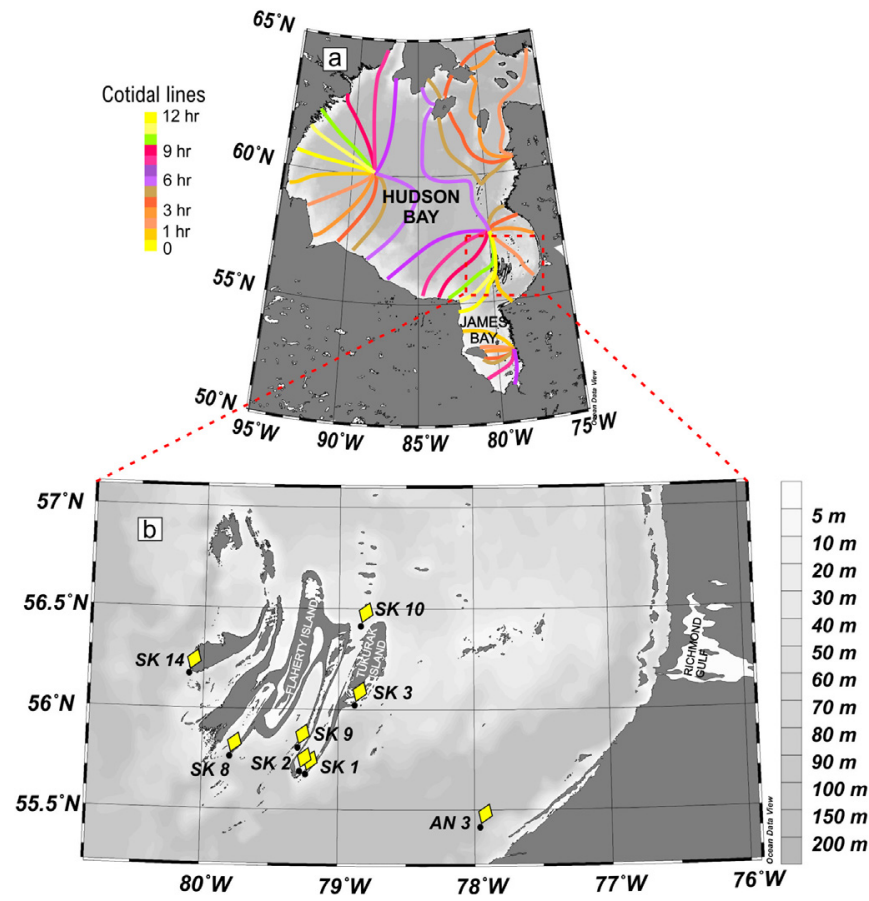

Fig. 1. (a) Hudson Bay and $M_{2}$ amphidromic points and hourly cotidal lines with phase intervals of $\sim 30^{\circ}$ (adapted from St-Laurent et al. 2008). (b) The bathymetric map of the Belcher Islands region and location of the 2014 sampling sites and ArcticNet 2003 mooring location (AN 3). Map data: Ocean Data View, GEBCO.

Saucier et al., 2004). The $\mathrm{M}_{2}$ tide in a form of a Kelvin wave propagates anticlockwise around Hudson Bay, partially entering James Bay at its southern end (Fig. 1) and partially proceeding along the east coast of Hudson Bay, before finally joining the incoming tide at Hudson Strait $25 \mathrm{~h}$ later (Prinsenberg and Freeman, 1986; Wang et al., 1994; Saucier et al., 2004; Chen et al., 2009). In the vicinity of the Belcher Islands, in south-east Hudson Bay, the maximum tidal heights reach $1.2 \mathrm{~m}$. Hudson Bay has one of world highest $\mathrm{M}_{2}$ tidal dissipation rates (Egbert and Ray, 2000). Two major $\mathrm{M}_{2}$ amphidromic points (shown in Fig. 1a) are connected by a nodal line and located in the central and east-central parts of Hudson Bay (Freeman and Murty, 1976; St-Laurent et al., 2008; Webb, 2014). St-Laurent et al. (2008) in their model study showed the existence of two secondary $\mathrm{M}_{2}$ amphidromic points: one located northeast of the latter major amphidrome and another one in the east-central part of James Bay (Fig. 1a). However, as pointed out by Chen et al. (2009), modeling of internal tides in Arctic and sub-Arctic regions including Hudson Bay, especially during the ice-covered period, is very difficult without having accurate information on water stratification and parameters (sea-ice velocity, deformation, and ice-ocean drag coefficient) of drifting and land-fast ice.

Until now observations of internal tidal waves in Hudson Bay have not been conducted. The Belcher Islands archipelago is an interesting region for internal wave observations due to its unique shoreline and bottom topography (Fig. 1b) and its location near an amphidromic point such that the $\mathrm{M}_{2}$ tidal wave rotates counterclockwise around the islands. The sharp phase shift suggested by St-Laurent, see their Fig. 7) et al. (2008) drives currents through the narrow channels of Belcher Islands, creates many small latent heat polynyas, and could possibly influence internal wave development. Due to the large freshwater input to south-east Hudson Bay (Granskog et al., 2009b, 2011; Macdonald and Kuzyk, 2011), this region also has higher mean water column stratification compared to northeast Hudson Bay and Hudson Strait (Ferland et al., 2011).

The main objectives of our study are: (1) to describe and examine the water column structure and internal tidal waves recorded under land-fast ice in southeast Belcher Islands using temperature, salinity and current velocity data acquired in winter and (2) to describe the spatial patterns of short-period internal waves observed in satellite synthetic aperture radar (SAR) images of the study site during the icefree season. The combination of winter under-ice in situ time-series measurements using land-fast sea ice as a stable measurement platform and the spatial information from satellite observations of ice-free areas provided a detailed picture of tidal dynamics in this Arctic region.

\section{Material and Methods}

\subsection{Description of study area}

The Belcher Islands archipelago is a group of about 1500 islands located in southeast Hudson Bay (ca) downstream of a large freshwater runoff input originating from James Bay. It is composed of a group of long and narrow islands and peninsulas separated by narrow channels and fjords oriented mostly in a northeast-southwest direction and with numerous scattered small islands and outcrops (Fig. 1b). This unusually intricate topography of the Belcher Islands, which belongs to the Churchill tectonic province, is a result of folding of unmetamorphosed Proterozoic strata into double plunging folds (Jackson, 1960). Ice-rafted material ( $>20 \%$ of bottom sediment) additionally adds complexity to the seafloor that is mainly composed of silt or sand (Pelletier, 1968).

During winter a number of coastal polynyas are formed around the islands providing open water areas, which are crucial for marine habitat (Heath et al., 2006). Polynyas and ice formation with brine release affect salt balance during winter, while during summer, the coastal waters surrounding the Belcher Islands are affected by significant freshwater runoff from neighbouring James Bay $\left(\sim 350 \mathrm{~km}^{3} / \mathrm{yr}\right.$ ) (Déry et al., 2011; Granskog et al., 2011). A number of major rivers, including the La Grande Rivière that discharges into James Bay, are now regulated as a result of hydroelectric development causing increased winter freshwater runoff (Déry et al., 2005, 2009, 2011) that help maintain surface stratification despite ice formation.

Hudson Bay is ice-covered for 8-9 months a year with ice formation typically starting in the north-west corner of the bay in late October (Hochheim and Barber, 2014). In places, there is a steady growth in ice thickness from January until April (Granskog et al., 2009a). The mean maximum ice thickness varies from $1.17 \mathrm{~m}$ in north-western Hudson Bay to $1.67 \mathrm{~m}$ in its eastern part, where the Belcher Islands are located (Landy et al., 2017). Around the Belcher Islands, the ice usually starts forming in December and breaks up in June (Hochheim and Barber, 2014; Eastwood, 2018).

In the winter of 2013-2014, sea ice started to form around the Belcher Islands in mid-December. The land-fast ice around the islands was formed by early January but large periodical opening and closing of leads up to $150 \mathrm{~km}$ long persisted throughout the winter both to the west and north of the islands (Figs. 2a and 2b). Besides these large leads, there were smaller polynyas close to the south-east tip of the islands and along the eastern shore (Fig. 2a). Such polynyas can significantly affect water circulation patterns in coastal areas, fjords and narrow channels (e.g., Dmitrenko et al., 2012, 2015). In coastal areas, a polynya produces frazil ice with associated brine release (Dmitrenko et al., 2010) and significant weakening of density stratification (Dmitrenko et al., 2012). When a polynya is present at the mouth of a fjord or a channel, brine release can enhance water circulation replenishing fjords' intermediate water layer with polynya generated water (Dmitrenko et al., 2015). This enhanced brine-related circulation also drives biological processes such as diel vertical migration of zooplankton (Petrusevich et al., 2016).

\subsection{Mooring Setup}

In our study, we deployed ice-tethered moorings and conducted CTD sampling below the sea-ice cover throughout the three winter 

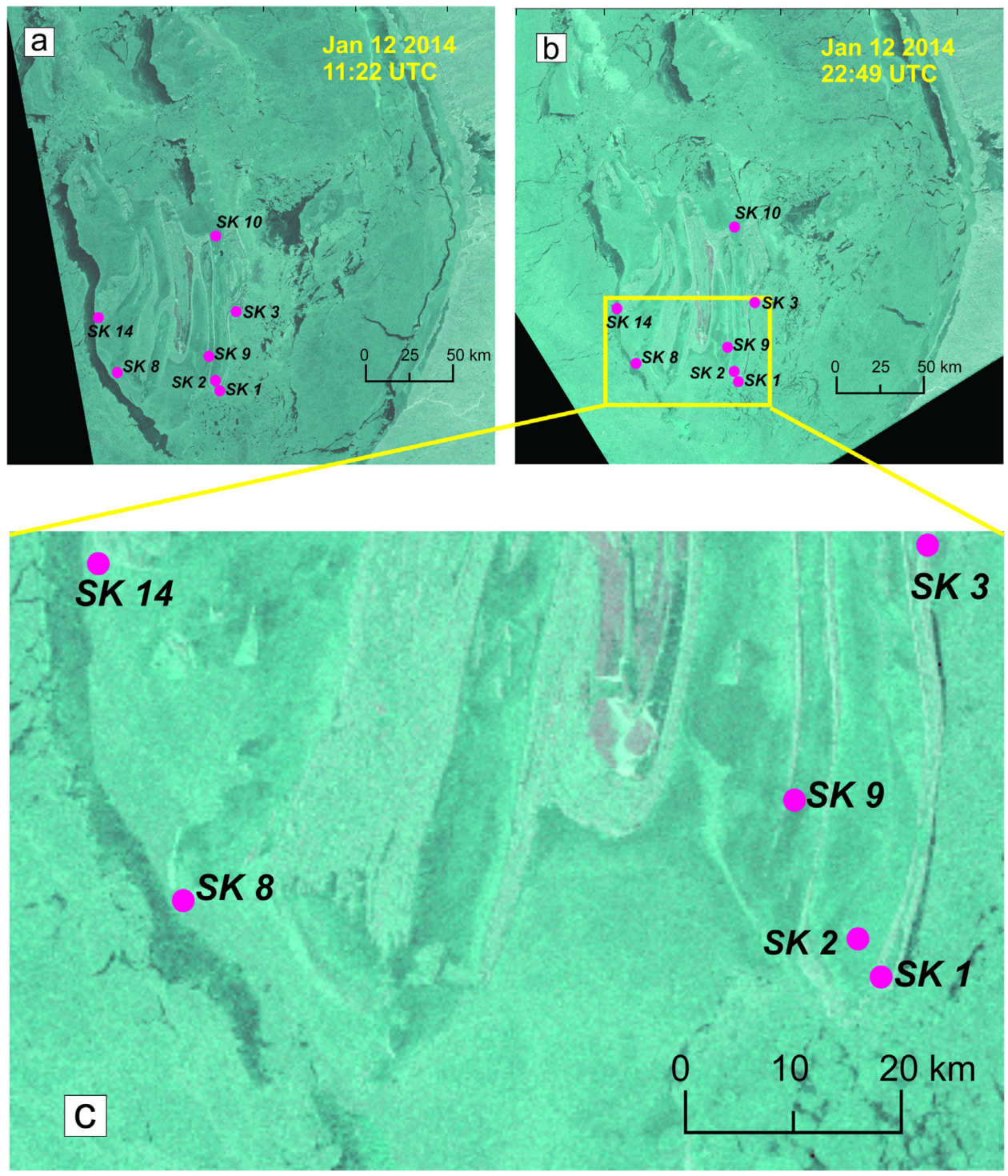

Fig. 2. RADARSAT-2 images of the Belcher Islands region taken on January 12th, 2014 with an overlay of sampling locations. RGB image $($ Red $=H V$, Blue $=$ HH, Green $=\mathrm{HH}$ ). (For interpretation of the references to color in this figure legend, the reader is referred to the web version of this article).

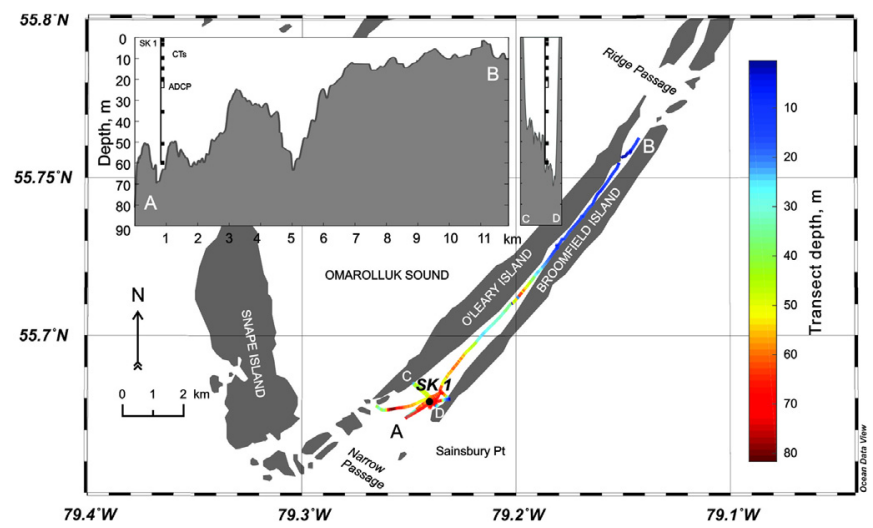

Fig. 3. Bathymetry transect obtained in October 2016 along the narrow channel between Broomfield and O'Leary islands located at the south-east tip of the Belcher Islands group. Insets: measured depth along the transect line $\mathrm{AB}$ and across the channel CD at the mooring SK1 location. Map data: Ocean Data View, GSHHG. months of January-March 2014. The ice-tethered mooring placed at the SK1 location $(55.68105 \mathrm{~N}, 79.24009 \mathrm{~W}, 65 \mathrm{~m}$ water depth, Fig. 1b) consisted of nine conductivity and temperature (CT) sensors and one acoustic Doppler current profiler (ADCP). The SK1 station was located in a narrow channel (maximum width $1.25 \mathrm{~km}$ ) between Broomfield and O'Leary islands at the south-east tip of the Belcher Islands archipelago (Fig. 3). This site was selected as the most proximal point to James Bay freshwater outflows having stable sea ice conditions that would maintain an ice-tethered mooring throughout the winter months January-March.

The CT sensors were JFE ALEC Compact-CT ACT-HR and were placed at $1.5,3,5,10,15,20,35,50$, and $60 \mathrm{~m}$ depths. According to the manufacturer's estimates, individual temperature and conductivity measurements are accurate to $\pm 0.02{ }^{\circ} \mathrm{C}$ and $\pm 0.02 \mathrm{mS} / \mathrm{cm}$ respectively. One CT sensor deployed at $5 \mathrm{~m}$ depth failed after 1 February 2014.

The ADCP was a Nortek Aquadopp Z-cell $600 \mathrm{kHz}$ current profiler moored at $20 \mathrm{~m}$ depth looking upwards. According to the manufacturer, the ADCP velocity precision and resolution were $\pm 1 \%$ and $\pm 0.5 \mathrm{~cm} /$ $\mathrm{s}$, respectively. Compass accuracy was $\pm 2^{\circ}$ with $0.1^{\circ}$ resolution and was corrected by adding magnetic declination $\left(-16.0^{\circ}\right)$. Velocity measurements were collected from the surface down to $20 \mathrm{~m}$ depth at $1 \mathrm{~m}$ cell size every $1 \mathrm{~h}$ with a 10-min average interval. 


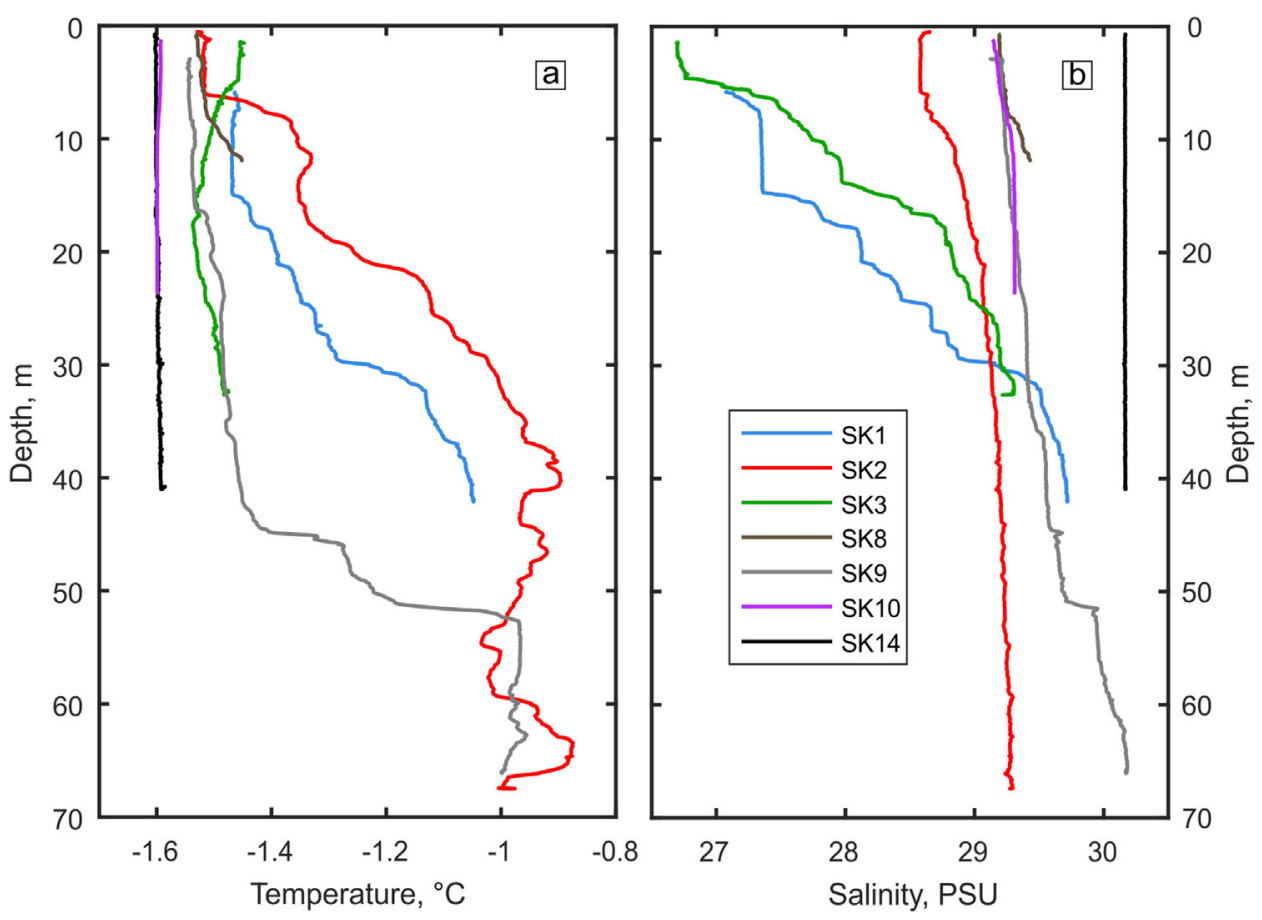

Fig. 4. Temperature (a) and salinity (b) profiles taken at the sampling sites SK1-SK14 in January-February 2014.

\subsection{CTD casts}

The mooring data were complemented by CTD casts made at various stations (SK1, SK2, SK3, SK8, SK9, and SK10) surrounding the Belcher Islands (Fig. 1b) in January and February 2014. The CTD casts were conducted using a CTD manufactured by RBR with temperature accuracy $\pm 0.002{ }^{\circ} \mathrm{C}$, conductivity accuracy of $0.001 \mathrm{mS} / \mathrm{cm}$ and pressure (depth) accuracy of $\pm 0.05 \%$ full scale.

\subsection{Bathymetry measurements at mooring location}

In October 2016, a bathymetric survey was conducted in the narrow channel between Broomfield and O'Leary islands where the mooring SK1 was deployed in 2014 (Fig. 3). The survey was about $10 \mathrm{~km}$ long and ran along the approximate middle of the channel from the northern area down to the location of the mooring SK1 (Fig. 3). The bathymetric survey was performed using 50/83/200 kHz Lowrance HDS-5 $200 \mathrm{kHz}$ and multi-frequency CHIRP Raymarine WI-FISH sonars.

The bathymetric survey revealed that the northernmost $\sim 1 \mathrm{~km}$ of the channel between Broomfield and O'Leary islands is relatively shallow with depths varying between 10 and $20 \mathrm{~m}$ (Fig. 3). Proceeding to the south, the channel becomes very shallow with variable depths less than $10 \mathrm{~m}$ and some shallow spots less than a meter all the way across the channel. From this shallow area, the sea bed slopes gradually down towards the south for $6 \mathrm{~km}$ reaching a maximum water depth of $30 \mathrm{~m}$. Approximately halfway down the length of the channel, there is a $1 \mathrm{~km}$ stretch of abruptly changing topography with depths varying from 20 to $60 \mathrm{~m}$ within $200 \mathrm{~m}$ sections. South of this point, for another $2 \mathrm{~km}$, there is a relatively smooth stretch sloping up from $40 \mathrm{~m}$ to $25 \mathrm{~m}$ and then dropping down to $50-60 \mathrm{~m}$. The channel is about $70 \mathrm{~m}$ deep in the proximity of the SK1 mooring location but the depth varies by up to $20 \mathrm{~m}$ within $400 \mathrm{~m}$ of the site in a cross-channel direction (inset CD, Fig. 3). Two distinctive sill-like features rising $\sim 20 \mathrm{~m}$ above the mooring depth are located within $1 \mathrm{~km}$ south-east and north-west of the mooring, and another one rising $\sim 45 \mathrm{~m}$ is located $2.5 \mathrm{~km}$ north-east of the mooring (Fig. 3, insets).

\subsection{Satellite observations during the ice-free season}

The winter-time field measurements were complemented by spaceborne Sentinel-1A and 1B SAR observations to document the internal wave activity around Belcher Islands during the ice-free season. Such observations have recently proved to be effective for inferring the detailed 2-D structure and kinematics of tidally-generated internal waves and identifying local mixing hot spots over the various Arctic Ocean regions (Kozlov et al., 2014, 2017; Morozov et al., 2017).

Sentinel data used for this study were obtained from the Copernicus Open Access Hub (https://scihub.copernicus.eu). The SAR data represent high and medium resolution Ground Range Detected (GRD) images (Level 1 Product) taken in Interferometric Wide swath and Extra-Wide swath modes with a spatial resolution of about $20 \mathrm{~m}$ and $90 \mathrm{~m}$, respectively. The original SAR data were first calibrated to normalized radar cross-section units following Miranda and Meadows (2015), and then normalized to remove the signal trend in the range direction. Finally, the SAR images were smoothed using the adaptive Wiener filter (Lim, 1990) with a moving $5 \times 5$ pixel window. In total, 107 Sentinel-1A and 1B SAR images were analyzed spanning May-November 2015 and 2016, and May-September 2017. Identification and analysis of internal solitary waves (ISWs) in SAR images were performed using the methodology described in Kozlov et al. (2015).

\section{Results}

\subsection{Temperature and salinity profiles}

CTD profiles (Fig. 4) measured at SK1-SK3 and SK8 towards the south end of the Belcher Islands showed the presence of a colder and fresher layer in the upper $5-15 \mathrm{~m}$. The temperature at SK1 was $-1.4{ }^{\circ} \mathrm{C}$ all the way down to $15 \mathrm{~m}$ with salinity of $27 \mathrm{PSU}$ in the top $5 \mathrm{~m}$ and 27.3 PSU between $5 \mathrm{~m}$ and $15 \mathrm{~m}$ depth. At SK2, the temperature was around $-1.55^{\circ} \mathrm{C}$ and salinity was 28.6 PSU in the upper $5 \mathrm{~m}$ (Fig. 4). Below $5 \mathrm{~m}$, temperature and salinity increased sharply, reaching $-1.35^{\circ} \mathrm{C}$ and $28.8 \mathrm{PSU}$ at $\sim 8 \mathrm{~m}$ depth. Below $8 \mathrm{~m}$, salinity stayed around $29 \mathrm{PSU}$, but at $21 \mathrm{~m}$ depth, temperature underwent another step increase to $-1.1^{\circ} \mathrm{C}$ (Fig. 4). 
The temperature and salinity profiles taken at SK9 have a similar pattern to those at SK2 but the cold $\left(-1.55^{\circ} \mathrm{C}\right)$ surface layer extends much deeper (down to $44 \mathrm{~m}$ ) and it is slightly more saline (29.2 PSU) than at the other locations. Two halocline features were observed at $45 \mathrm{~m}$ and $51 \mathrm{~m}$. Below $51 \mathrm{~m}$ depth, there was a warmer $\left(-0.9^{\circ} \mathrm{C}\right)$ and more saline (30 PSU) deep layer.

In the CTD profiles taken around the Belcher Islands, a number of distinctive common features were observed. The first feature was the fresher surface layer with salinity decreasing towards the southeast. The fresher surface layer that exists in summer to the southeast of the Belcher Islands is caused by cyclonic transport of surface waters containing river runoff and ice-melt in Hudson Bay (Prinsenberg, 1986a, 1986b, 1987). This study and Eastwood (2018) are the first to report the presence of this fresher surface layer in southeast Hudson Bay in winter. Tracer $\left(\mathrm{S}, \delta^{18} \mathrm{O}\right)$ work has shown that river water dominates the freshwater content in this area in winter (Eastwood, 2018). The presence of river water defines a SW-NE coastal domain, with SE portions more strongly stratified by river water and NW regions saltier and vertically mixed.

Second, CTD profiles show a trend towards warmer and fresher water in the bottom layer when going from the north southwards around the Belcher Islands towards SK1 and SK2 (Fig. 1b). SK2 was quite different from SK1 but similar to SK10 and SK9. SK1 was more similar to SK3, which we speculate may be caused by restricted flow through the channel. The CTD profiles taken at SK1 during mooring deployment and retrieval (Figs. 9a and 9b, blue lines) show reductions occurring over the course of the winter in both the temperature and salinity in the bottom water layer below $30 \mathrm{~m}$ depth. The presence of warm bottom water in this region in early winter was also observed by an ArcticNet AN 3 mooring (Fig. 1b) deployed in 2010 at $55.408928 \mathrm{~N}$, $77.930998 \mathrm{~W}(20 \mathrm{~km}$ NW of the village of Kuujjuraapik, $85 \mathrm{~km}$ ESE of mooring SK1 location). AN 3mooring data at $92 \mathrm{~m}$ depth showed a low temperature of about $-1.3^{\circ} \mathrm{C}$ in early October 2010 , rising temperature trend through the fall to peak at $+2.5^{\circ} \mathrm{C}$ in mid-December, then gradual cooling down to near-freezing temperatures by the end of March 2011 (unpublished data not shown). Thus, the warm bottom water observed at the SK1 mooring site appears to be a regional feature, established prior to freeze up, which gradually cools and freshens through the winter.

Finally, CTD profiles taken in the southern locations SK1, SK2, SK8 and SK9 reveal the presence of staircase patterns as shown in Fig. 4. The staircase consists of multiple density layers with constant temperature and salinity, separated by thin interfaces of temperature and salinity increasing with depth. These transition layers range in thickness from $1 \mathrm{~m}$ to $3 \mathrm{~m}$ and collectively separate the cold and fresh surface water layer from the warm and salty water below. To assess the significance of these staircase patterns in terms of vertical mixing, the density stability ratio $R \rho$ can be calculated as follows:

$R_{\rho}=\frac{\alpha}{\beta} \frac{\Delta T}{\Delta S}$,

where $\alpha$ and $\beta$ are thermal and haline expansion coefficients, calculated from the equation of state (Roquet et al., 2015), and $\Delta T$ and $\Delta S$ are, respectively, the temperature and salinity vertical gradients. For SK1, the estimated values of $R \rho \sim 0.001$ are sufficiently smaller than 1 to conclude that despite the staircase appearance of the profiles, the snapshot double-diffusive fluxes are insignificant.

The additional CTD cast made in the proximity of SK1 on 1 August 2016 (Fig. 5, red line) showed a fresher ( $\geq 24.75$ PSU) and warmer $\left(\geq 11.3^{\circ} \mathrm{C}\right.$ ) surface layer than present in the winter. The depth of the upper pycnocline is slightly shallower than in winter ( $\sim 10 \mathrm{~m}$ vs. $15 \mathrm{~m})$ and the contribution of temperature to the vertical density gradient becomes stronger, leading to a more pronounced vertical stratification than in winter.

\subsection{Mooring data}

Figs. $6 \mathrm{a}$ and $6 \mathrm{~b}$ show time series of temperature and salinity, respectively, recorded by the ice-tethered mooring SK1 from 21 January to 18 March 2014. The main feature in these data is a pronounced semidiurnal periodic variability in temperature and salinity, which affects the entire water column beneath the land-fast sea ice cover throughout the period of record. The tidally driven variation will be discussed further below. In addition to the tidal component, an interesting feature in the records is an episode of isohaline and isothermal uplift of $\sim 10 \mathrm{~m}$, which is interpreted as upwelling. This event during 27-28 January interrupts the relative stability of the early portion of the mooring record, during which time relatively fresh surface waters with salinities in the range of 26-27 PSU were present at $1.5 \mathrm{~m}$ depth (Fig. 6). On 27 January, the vertical structure of the water column underwent a significant change manifesting in a sharp increase in both salinity and temperature at $1.5 \mathrm{~m}$ depth. The temperature of the surface layer increased by $0.2^{\circ} \mathrm{C}$ and the temperature at $35 \mathrm{~m}$ depth increased by $0.3^{\circ} \mathrm{C}$, while the salinity increased by $\sim 1$ PSU. Below $35 \mathrm{~m}$, there was a temperature decrease of $0.2{ }^{\circ} \mathrm{C}$ after 28 January, followed by an increase of $0.1{ }^{\circ} \mathrm{C}$ during 29-30 January.

The upwelling event occurred following a storm on 27-28 January 2014 , during which weather stations located $\sim 100 \mathrm{~km}$ from the mooring site (Fig. 7) recorded significant westerly and south-westerly winds. The Environment and Climate Change Canada (http://climate. weather.gc.ca/historical_data/) weather station at Sanikiluaq Airport (YSK) recorded westerly wind speeds up to $56 \mathrm{~km} / \mathrm{h}$, and the weather station at Kuujjuarapik Airport (YGW) recorded southwesterly winds up to $48 \mathrm{~km} / \mathrm{h}$. These weather stations are located about $100 \mathrm{~km}$ northwest and southeast, respectively, from the SK1 mooring site. There were no RADARSAT-2 data available for these days, however, a MODIS image acquired on 29 January immediately following the storm shows an open lead along the southeast shore of the island in the proximity of the mooring SK1 and multiple ice floes that appear to have been transported eastward away from the shore of the island during the storm event (Fig. 7). The apparent eastward drift of these ice floes supports the interpretation that westerly and south-westerly winds occurred at the study site and caused the upwelling recorded by the mooring.

Current profiler data, averaged over $24-\mathrm{h}$ periods, were used to calculate the residual currents for the top $20 \mathrm{~m}$ layer beneath the sea ice cover (Fig. 8). Even though the residual current direction varied at different depths and times, a mean southward transport along the channel was observed, which is opposite to the general cyclonic circulation in that area of Hudson Bay (e.g., Prinsenberg, 1986a). At the beginning of the record, a residual current maximal value of $0.16 \mathrm{~m} / \mathrm{s}$ was observed at $4 \mathrm{~m}$ depth. During the storm event on 27-28 January, the residual currents were first directed from NNW to SSE, that is, directed about $90^{\circ}$ to the wind direction (Fig. 8). Then, on 28 January, the residual currents shifted to being directed from NNE to SSW, i.e., aligned with the channel at SK1. This direction of currents corresponds to Ekman transport. The residual currents in the upper $10 \mathrm{~m}$ also doubled in value from maximal values of $0.14 \mathrm{~m} / \mathrm{s}$ before the storm to $0.27 \mathrm{~m} / \mathrm{s}$ after the storm. During the post-storm period, the residual currents reached a maximum speed of about $0.39 \mathrm{~m} / \mathrm{s}$ at $2 \mathrm{~m}$ depth gradually decreasing with depth down to zero at $20 \mathrm{~m}$.

Aside from the single event, the thermohaline structure remained rather stable with periodic semidiurnal temperature and salinity oscillations, as mentioned above. Tidal harmonic analysis performed for the temperature, salinity and velocity time series using T_Tide toolbox for Matlab (Pawlowicz et al., 2002), showed the dominance of the $M_{2}$ tidal constituent, while the $S_{2}$ tidal constituent was negligible.

From the mooring time series, the mean temperature and salinity were calculated for each instrument (Figs. 9a and 9b, black lines) and compared to the CTD casts taken during mooring deployment and retrieval (Figs. 9a and 9b, blue lines). Temperature and salinity profiles taken at the time of mooring retrieval (dashed blue line) mostly fell 

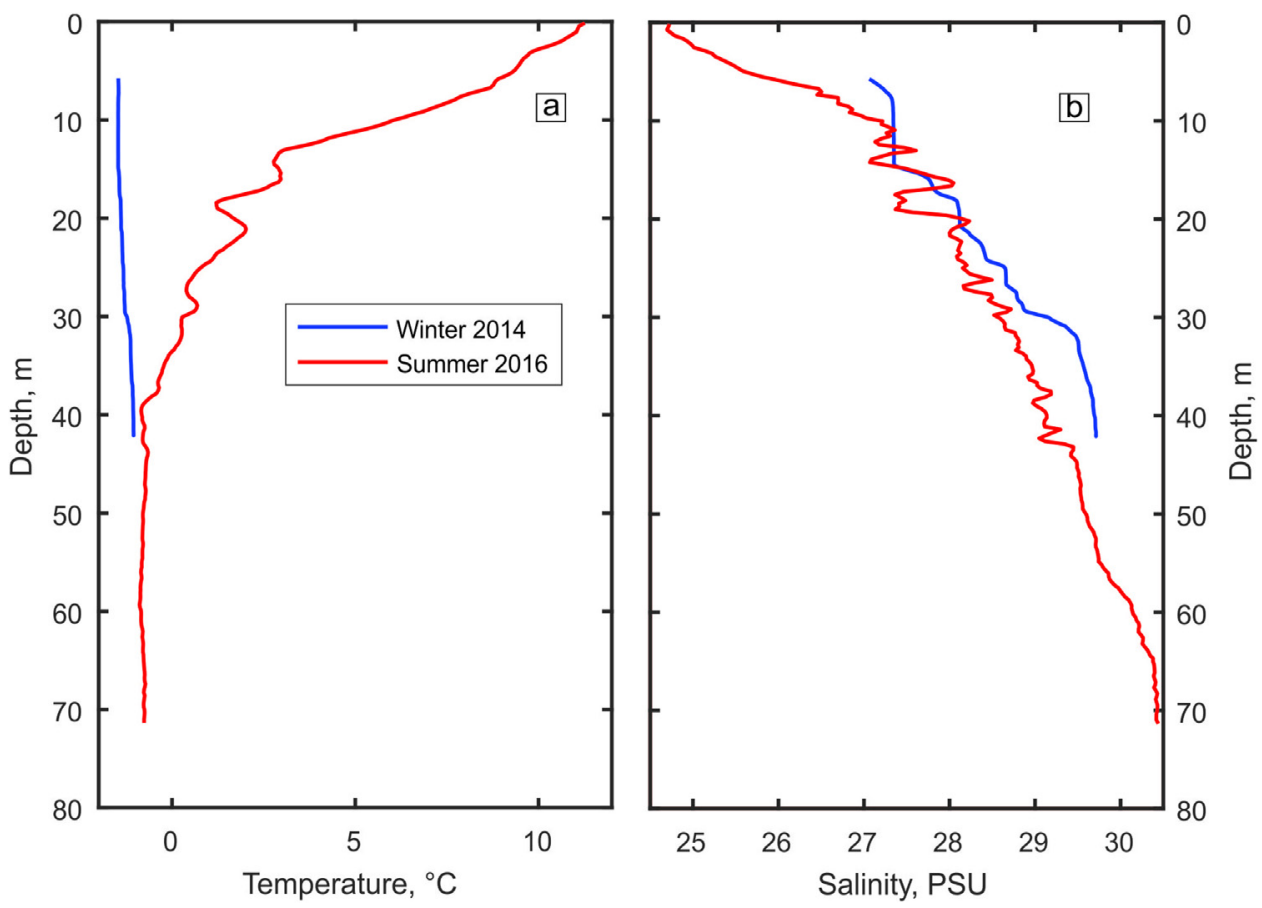

Fig. 5. Temperature (a) and salinity (b) profiles taken at SK1 on 21 January 2014 (blue line) and 2 km south-east from SK1 on August 1, 2016 (red line).(For interpretation of the references to color in this figure legend, the reader is referred to the web version of this article).
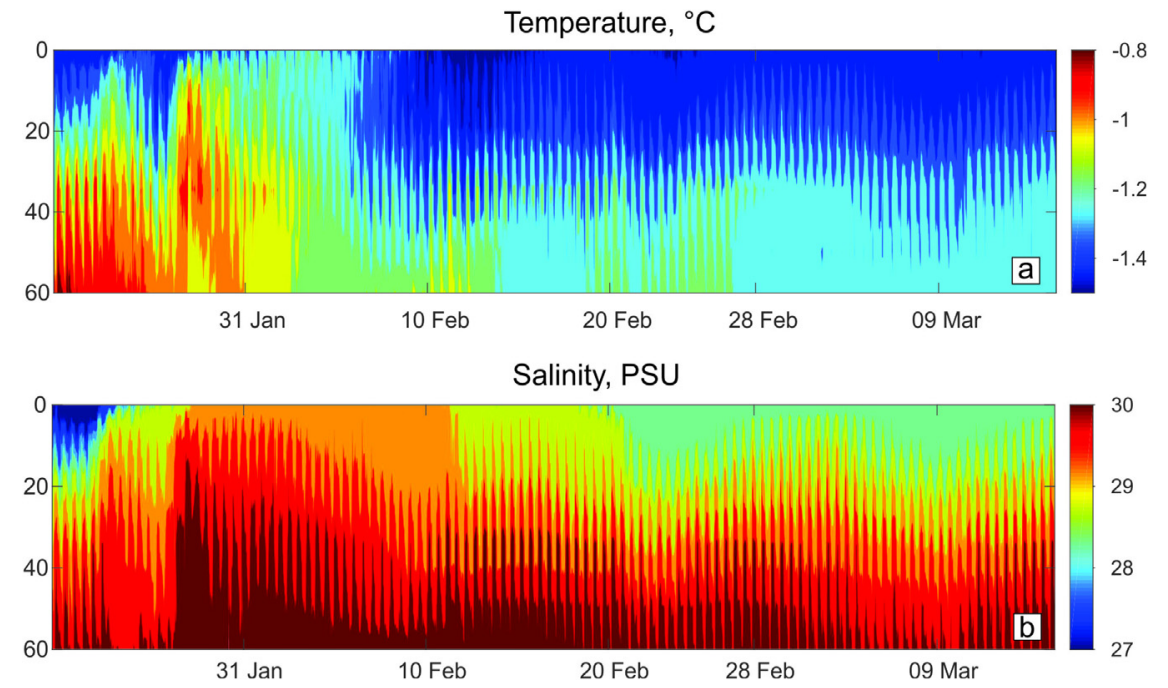

Fig. 6. Temperature (a) and salinity (b) time series at mooring site SK 1 from 21 January to 18 March 2014.

within the standard deviation of the calculated mean temperature and salinity. Besides that, from the tidal analysis, the $\mathrm{M}_{2}$ tidal temperature and salinity amplitudes were calculated for each depth (Figs. 9a and 9b, red lines). $\mathrm{M}_{2}$ fluctuations in temperature/salinity were less than $0.016^{\circ} \mathrm{C} / 0.029 \mathrm{PSU}$ at the surface and down to $5 \mathrm{~m}$ depth, and less than $0.003{ }^{\circ} \mathrm{C} / 0.053 \mathrm{PSU}$ near the bottom. The largest temperature/salinity semidiurnal fluctuations were observed at $35 \mathrm{~m}$ depth, where they reached $0.067^{\circ} \mathrm{C} / 0.385 \mathrm{PSU} . \mathrm{M}_{2}$ current fluctuations were stronger in the surface layer reaching up to $0.27 \mathrm{~m} / \mathrm{s}$.

Vertical displacements of the water parcels shown in Fig. 9c were calculated for both temperature (red line) and salinity (blue line) as a ratio of the $\mathrm{M}_{2}$ tidal temperature (or salinity) amplitude at a certain depth to the vertical gradient of the temperature (or salinity, accordingly) at the same depth. Vertical displacements derived from both temperature and salinity were statistically similar (that is, within one standard deviation) and displayed the maximum values at $35 \mathrm{~m}$ depth
(Fig. 9c). For example, at $35 \mathrm{~m}$ depth, the calculated vertical displacement was $11.9 \mathrm{~m}$ for temperature and $12.3 \mathrm{~m}$ for salinity, which corresponds to wave amplitude of about $6 \mathrm{~m}$.

The tidal ellipses (Fig. 10) were computed for horizontal velocities at $1.5,3,10,15$, and $20 \mathrm{~m}$ depths and were combined with corresponding temperature (Figs. 10a-10e) and salinity anomalies (Figs. 10f$10 \mathrm{j}$ ) obtained from the mooring CT sensors located at those depths. As expected, the major axes of $\mathrm{M}_{2}$ tidal ellipses were oriented along the channel, particularly in the near-surface layer. The horizontal velocity amplitudes ranged from a maximum of $0.27 \mathrm{~m} / \mathrm{s}$ below the ice at $1.5 \mathrm{~m}$ depth down to $0.05 \mathrm{~m} / \mathrm{s}$ at $15 \mathrm{~m}$ depth, which were of the same order as the residual currents at these depths. At $20 \mathrm{~m}$ depth, local maxima in the temperature and salinity anomalies were observed close to the major axis of the tidal ellipses (Figs. 10c and 10h) with a slight offset, which suggests some dynamics as will be described in Section 4. 


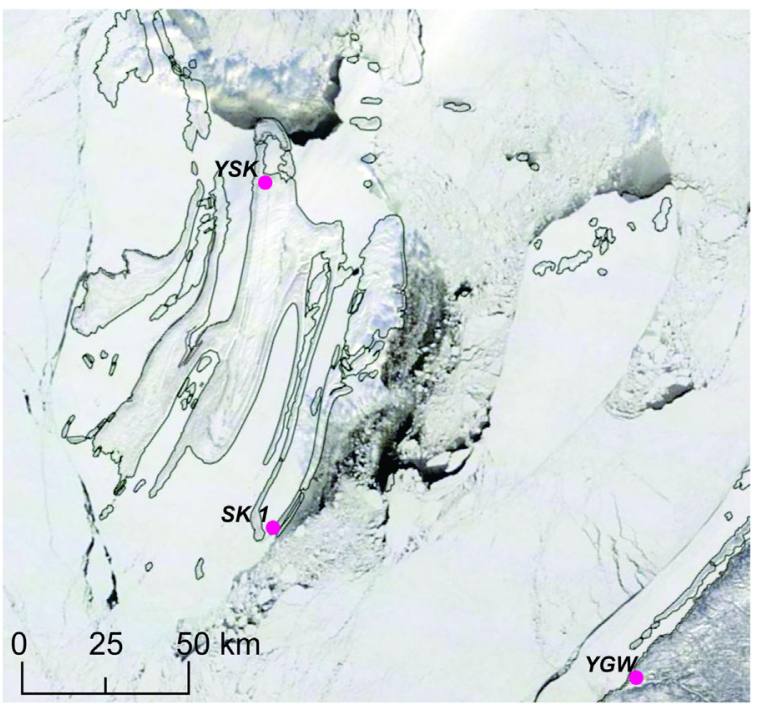

Fig. 7. EOSDIS (Terra/MODIS corrected reflectance and OpenStreetMap coastline) imagery of the Belcher Islands taken on 29 January 2014 shortly after the storm event. YSK - the location of Environment and Climate Change Canada weather station in Sanikiluaq Airport, YGW - weather station at Kuujjuarapik airport and SK1 mooring location.

\subsection{Satellite observations of internal waves near the Belcher Islands}

Analysis of spaceborne SAR data demonstrated a ubiquitous presence of internal solitary wave (ISW) packets over the study area throughout the ice-free season (June-November) (see Fig. 11, 22 July 2015 and 9 Aug 2016, for example). The earliest and latest ISW detections were 10 June and 19 November 2016, respectively.

Fig. 11 shows an early summer (a,b) and a late summer (c,d) example of the ISW fields near the Belcher Islands. Fig. 11a exhibits an internal wave packet observed by Sentinel-1 A on 22 July 2015 (22:55 UTC) approximately $65 \mathrm{~km}$ south-west of the Belcher Islands. The ISW packet was surrounded by melting chunks of drifting sea ice that covered the entire region south of the Belcher Islands. The central part of the packet was located in the open water area and the wave packet propagates in a southwest direction toward open water. The wave pattern was well expressed, which allowed counting of 13 individual solitary waves with rank-ordered intersoliton wavelengths of $0.3-1 \mathrm{~km}$. The length of the ISW train was about $8-10 \mathrm{~km}$, while its crest length reaches $40 \mathrm{~km}$. Fig. $11 \mathrm{~b}$ shows other ISW packets traveling both offshore and onshore including ISWs near the SK1 and SK8 stations. The ISW packets form an internal wave pattern, which was spreading from a point-like source in the vicinity of the southern tip of the Belcher Islands.

A SAR image acquired on 9 August 2016 when the study site was completely ice-free shows a similar ISW structure (see representation in
Fig. 11c-d). An enlarged fragment of the SAR image reveals four consecutive ISW trains, marked by letters from A to D, radially spreading towards the southwest (Fig. 11c). In the full image (Fig. 11d), six consecutive ISW trains were detected, which is a large number, rarely documented in the literature. The maximum observed intersoliton wavelength for these wave trains was $1.7 \mathrm{~km}$; their crests were as long as $200-250 \mathrm{~km}$, while the total observed travel distance was about $130-150 \mathrm{~km}$ from the presumed generation source located to the south of the Belcher Islands. The distance between these consecutive wave trains (representing the packet group wavelength) gradually rose for packets A-D, with a distance of about $16 \mathrm{~km}$ for A-B, 25-27 km for B-C, and $35 \mathrm{~km}$ for C-D. Thereafter, the packet group wavelength started to decrease, being $29 \mathrm{~km}$ for packets D-E and $24 \mathrm{~km}$ for packets E-F. This decrease corresponds to the wave packets encountering the shoaling bottom in southern Hudson Bay.

\section{Discussion}

The discussion section is organized as follows. First, we discuss the tidal oscillations of temperature and salinity recorded by the ice-tethered mooring, and consider internal tidal waves as a possible source for the vertical displacements. Second, we describe the main mechanisms for internal tidal wave generation. Lastly, we discuss the origin of the observed internal solitary wave (ISW) packets, their patterns, propagation and conditions for their generation.

\subsection{Internal tidal waves under land-fast ice}

Throughout the entire mooring record, semidiurnal oscillations of temperature and salinity at the $\mathrm{M}_{2}$ tidal frequency were observed. These oscillations could be caused by vertical displacements associated with semidiurnal internal tidal waves. Indeed, there are several considerations supporting this interpretation:

1. The alternative hypothesis that horizontal motion is the source of the temperature and salinity oscillations is very unlikely. It was shown by Kirillov et al. (2013) that the direction of horizontal temperature/salinity gradients is $90^{\circ}$ to the orientation of maximum/minimum temperature/salinity anomalies at tidal ellipses. In our case, the tidal ellipses were oriented along the channel and along the mean current flow. For depths at or below $10 \mathrm{~m}$ (Figs. 10c$10 \mathrm{e}$ and $10 \mathrm{~h}-10 \mathrm{j}$ ), the maximal amplitudes of temperature and salinity anomalies were located at or close to the apex points. If the horizontal motion is suggested as a source of such anomalies, the temperature/salinity gradient should be oriented across the channel and the mean flow, which is very unlikely. Thus, we conclude that the possible source of the temperature and salinity anomalies is vertical motion and not horizontal. At $1.5 \mathrm{~m}$ and $3 \mathrm{~m}$ depths, the maxima of $\mathrm{M}_{2}$ amplitudes were located at the base points of ellipses (Figs. 10a, 10b, 10f and 10g) but they were significantly less than the maximum anomalies at the apexes of the ellipses at lower

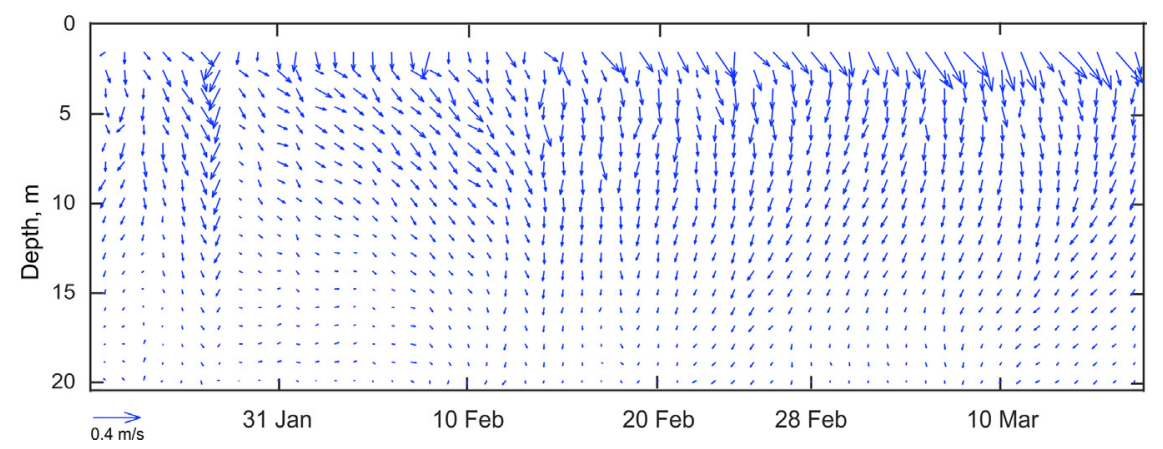

Fig. 8. Residual currents (North - up, East - right) for the top $20 \mathrm{~m}$ at mooring location SK1 derived from the 2014 ADCP data. 

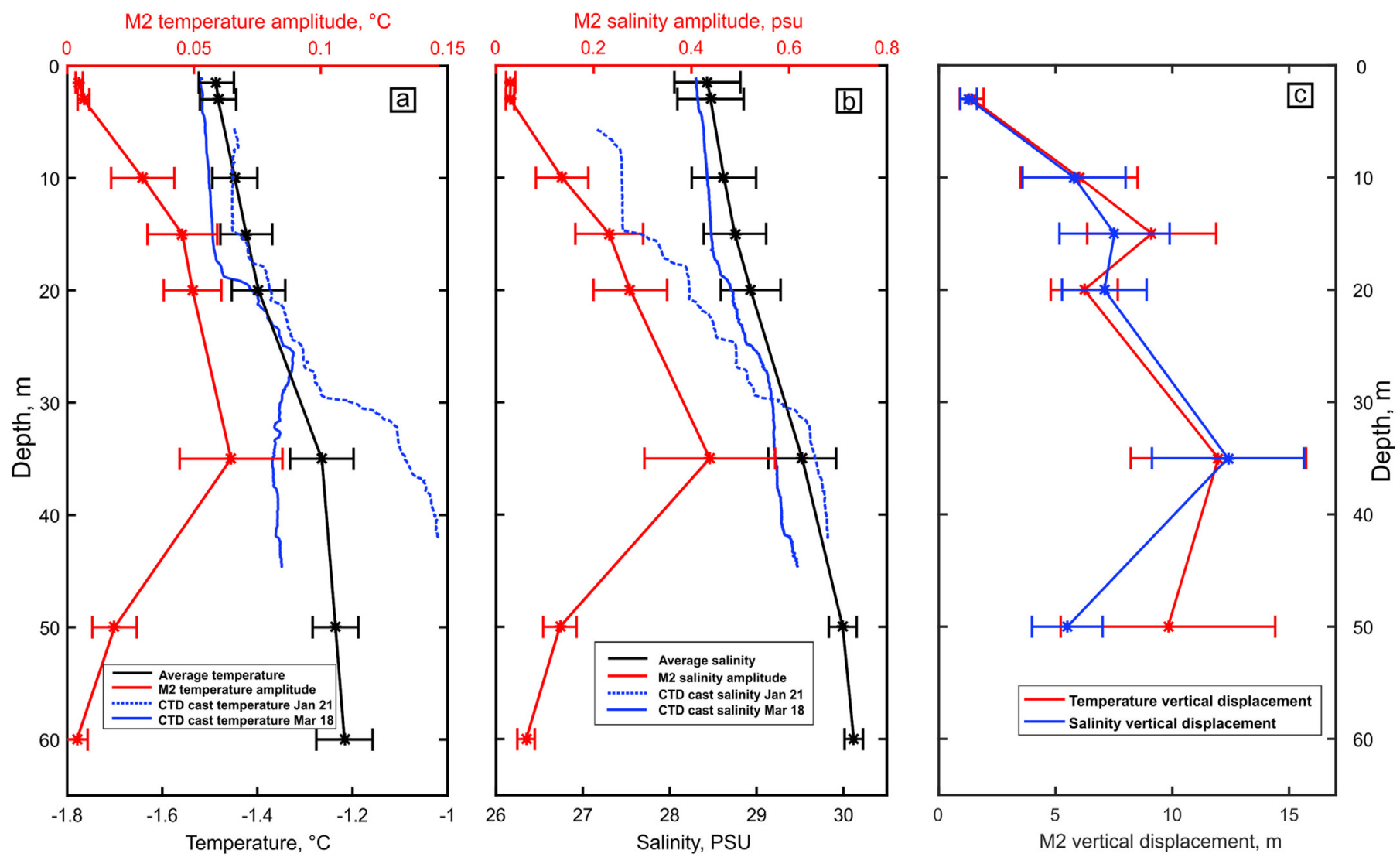

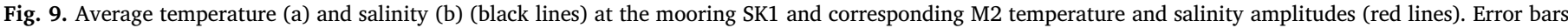

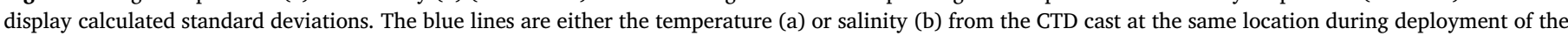

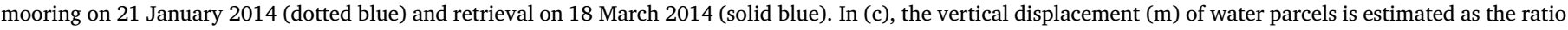

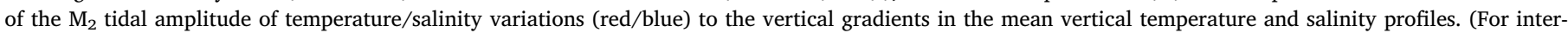
pretation of the references to color in this figure legend, the reader is referred to the web version of this article).

depths. The maximum anomalies in the $1.5-3 \mathrm{~m}$ layer were, for temperature, $0.013{ }^{\circ} \mathrm{C}$ vs. $0.038^{\circ} \mathrm{C}$ at $20 \mathrm{~m}$ depth (Figs. 10a, 10b, $10 \mathrm{f}$ and $10 \mathrm{~g}$ ), and for salinity, 0.03 PSU vs. 0.20 PSU at $20 \mathrm{~m}$ depth (Figs. 10e, 10j).

2. With reference to the distribution of $\mathrm{M}_{2}$ fluctuations of temperature and salinity with depth, the minimum values were observed in the surface layer and near the bottom (Figs. 9a and 9b, red lines), and the maximum was observed at $35 \mathrm{~m}$. The calculated vertical displacements for temperature and salinity were found to be statistically similar to each other and reaching maximum values at $35 \mathrm{~m}$ depth (Fig. 9c), which supports the idea that temperature and salinity fluctuations at the tidal frequency were caused by vertical displacements.

3. The shape of the vertical displacement profile (Fig. 9c) was very similar to the shape of vertical displacement of the first-mode internal tide (Alford, 2003) with two minima at the surface and the bottom and one maximum, and possibly minor contribution of higher internal modes. Similar vertical displacements caused by internal waves were observed by Staalstrøm et al. (2012) in the silled Oslofjord during the ice-free season. In that work, the vertical displacements were not entirely associated with the first-mode internal tide but additionally with higher internal modes controlled by stratification. For SK1, a well-pronounced density stratification and a rough bottom topography are observed. Although a sill is not present in the mouth of the channel near SK1, there are several silllike features present inside the channel. This bathymetry suggests a baroclinic structure of the internal tide as was revealed in Fig. 9.

\subsection{The mechanisms of internal tidal wave generation}

There are three main mechanisms of internal tidal wave generation. First, there is generation of internal waves at the interface of two stratified layers caused by the tidal movement of water between the continental shelves and the deep ocean (Garrett, 2003). Second, internal waves can be generated by the interaction of tidal currents with the bottom in the presence of a sloped shore such as typically found at the mouth of a fjord (c.f. Farmer and Freeland, 1983). Here, we can rule out tidal flow interaction with a sloped shore because there is a rather abrupt shoreline in the channel entrance near SK1. A third possible mechanism is barotropic tide interaction with abrupt changes in bottom topography such as sills (St. Laurent et al., 2003; Jackson et al., 2012). From our bathymetric survey (Fig. 3), we were not able to confirm the presence of a sill in the mouth of the channel. However, the survey shows rough bottom topography with rises and falls in the order of $\sim 10 \mathrm{~m}$ over $100 \mathrm{~m}$ of the transect. We also described three sill-like features near the mooring location (Fig. 3, inset). At such banks or silllike features located below the halocline, internal wave packets are readily generated (Maxworthy, 1979; Haury et al., 1979; Jackson et al., 2012). Morozov et al., $(2008,2017)$ described phase-locked shortperiod internal waves generated in the Kara Gates that propagate together with internal tidal waves (internal bore) and caused by modification of barotropic tidal flow over underwater slopes and ridges, and further nonlinear evolution of the baroclinic tide. The analysis of satellite SAR observations for the ice-free season confirmed a wide presence of tidally generated short-period internal waves near SK1 and around the southern part of the Belcher Islands. Nonlinear internal waves similar to those reported in this study are the first-mode internal 

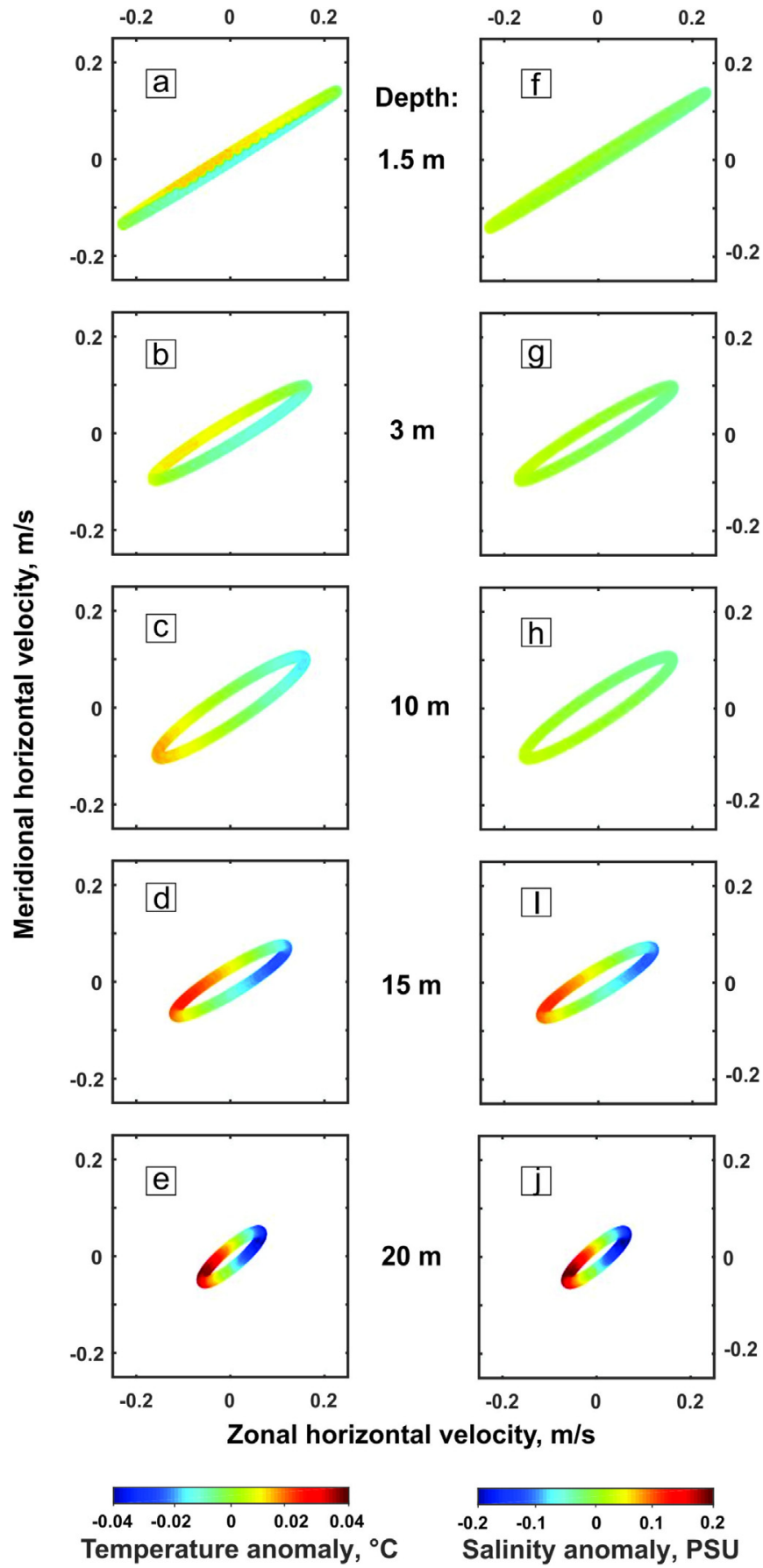

Fig. 10. Tidal ellipses (zonal and meridional horizontal velocity components) for various depths with corresponding temperature and salinity anomalies. The rotational direction of all tidal ellipses is counterclockwise.

waves (Jackson et al., 2012). We note that the winter-time vertical displacement profiles also show first-mode structure (Fig. 9).

\subsection{The origin of internal solitary waves}

The regular pattern of ISW to the southwest of the Belcher Islands suggests that these wave trains have a tidal origin and were likely generated by the $\mathrm{M}_{2}$ barotropic tide interacting with the vertical stratification over rough bottom topography south of the Belcher Islands. Assuming that these wave trains are phase-locked with semidiurnal tides, the observed packet group wavelengths of $16-36 \mathrm{~km}$ (as reported above) may be translated into an estimate of the average propagation speed of ISW packets (Robinson and da Silva, 2010). This calculation yields a range of ISW phase speeds of $0.36-0.8 \mathrm{~m} / \mathrm{s}$.

We note that packet A in Fig. 11d was located just $15-20 \mathrm{~km}$ from the southern tip of Flaherty Island (Fig. 1b). The small semicircular shape of this packet suggests that it was recently generated not far from its location in the SAR image, presumably over a bank or sloping bottom south of Flaherty Island. A plausible generation site, as suggested by the satellite data, for the group of ISW trains A-F is marked by the asterisk in Figs. 11c-11d.

Generation of offshore propagating nonlinear internal waves over a rough topography may be explained by the lee-wave generation mechanism (Jackson et al., 2012). In this case, the packets of short-period ISWs evolve from hydraulic jumps generated by the barotropic tidal flow on the lee side of underwater obstacles. In this case, the release of ISW trains is governed by the criticality of the flow defined by the Froude number, $F=U / C_{0}$, where $U$ is the total fluid velocity and $C_{0}$ is the linear phase speed of the first vertical internal mode. ISWs are thought to be generated when the tidal flow slackens and turns subcritical, i.e. when the Froude number transitions from supercritical $(F>1)$ to subcritical $(F<1)$ (see more details e.g. in Jackson et al., 2012). A summer CTD cast made in the proximity of SK1 on 1 August 2016 (Fig. 5), i.e. eight days prior to the SAR acquisition, allows us to estimate the phase speed of the lowest internal mode following (Phillips, 1977):

$C_{0}=\left(\frac{\delta \rho}{\rho} \frac{g}{k}\right)^{1 / 2}[\operatorname{coth} k h+\operatorname{coth} k(H-h)]^{-1 / 2}$,

where $\mathrm{k}$ is the wavenumber calculated for the maximum observed intersoliton wavelength of $1.7 \mathrm{~km}$, the characteristic depth $H=71 \mathrm{~m}$, the characteristic depth of upper layer $h=10 \mathrm{~m}$, and the relative density difference $\frac{\delta \rho}{\rho}=1.9 \times 10^{-3}$. From Eq. (2) we obtain $C_{0}=0.40 \mathrm{~m} / \mathrm{s}$, which falls within the SAR-derived phase speed values. For winter observations at SK1, the characteristic depth $H=60 \mathrm{~m}$, the characteristic depth of upper layer $h=15 \mathrm{~m}$, the relative density difference $\frac{\delta \rho}{\rho}=1.5 \times 10^{-3}$ and calculated phase speed $C_{0}=0.41 \mathrm{~m} / \mathrm{s}$. According to the observations, the total (tide + residual) current velocity $U$, measured at SK1 station during winter months ranged between 0.1 and $0.6 \mathrm{~m} / \mathrm{s}$, with corresponding Froude numbers ranging between 0.24 and 1.46. These values are consistent with a transitioning of the Froude number from supercritical to subcritical, suggesting that a lee-wave generation mechanism is plausible for the wintertime under the ice. We should also note that the observed ISW propagation direction (south-west) qualitatively coincided with the orientation of the tidal ellipses at the SK1 mooring location in winter (Fig. 10).

Fig. 12 shows a wider picture of ISW observations in southeast Hudson Bay and around the Belcher Islands. The map consists of 234 single ISW trains derived from 13 selected Sentinel SAR images acquired between June and November of 2015-2017. ISW manifestations were detected in all ice-free months from June to November. ISW trains were observed mostly in the central part of southeast Hudson Bay, southwest of the Belcher Islands. Based on the orientation of the wave trains, there is an apparent source area of ISW generation near the southwest tip of the Belcher Islands (Fig. 12). Most of the observed ISW trains propagated away from shallow coastal areas, either the Belcher Islands or one of the islands or shoals in the chains of the islands that extend north from the Belchers. One may also note a small group of ISW trains east of the Belcher Islands (shown in red in Fig. 12). This group of ISW trains was found over a shallow area lying immediately west of Richmond Gulf (Lac Guillaume-Delisle), which is a large brackish lake with strong river discharge. In this area, generation of internal waves may result from interaction of tides with a density front produced by the outflow of brackish waters from the lake. More details about the tide-front interaction mechanism of ISW generation may be found e.g. in Nash and Moum (2005) and Groeskamp et al. (2011). 

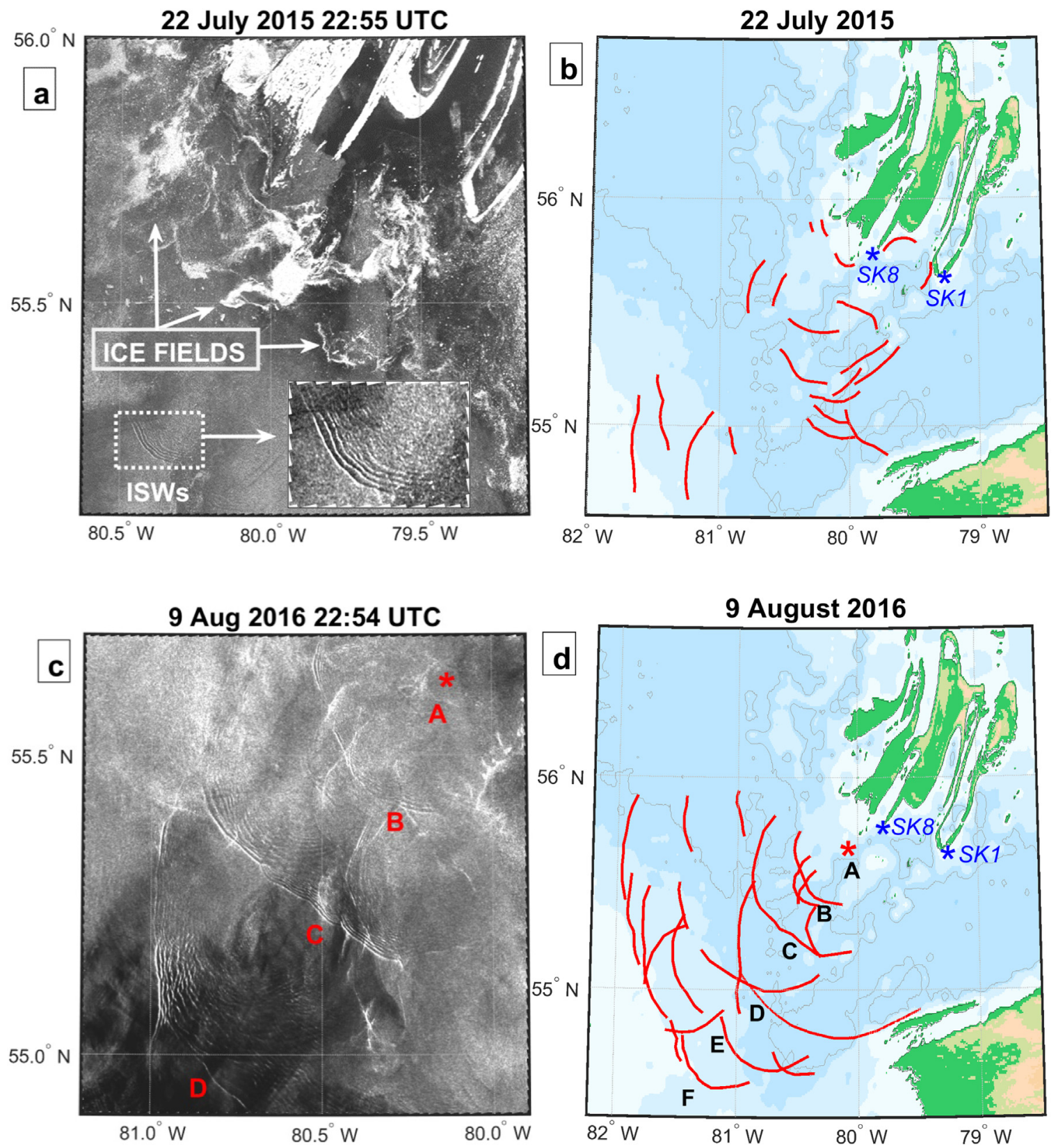

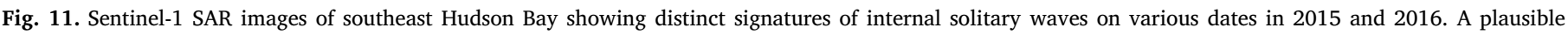

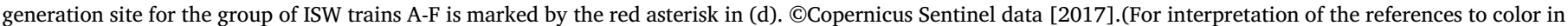
this figure legend, the reader is referred to the web version of this article).

\section{Conclusions}

While this study provides only some initial observations of internal waves in Hudson Bay, a combination of winter-time under-ice in situ measurements and summer-time spaceborne SAR observations provided a rather detailed picture of the tidal dynamics in this Arctic region. Tidal-driven oscillations of velocity, temperature, and salinity throughout the whole water column were observed in a channel at the south-east tip of the Belcher Islands group. Vertical displacements of water parcels derived from both temperature and salinity records were statistically similar and displayed a maximum value of $11.9 \mathrm{~m}$ at $35 \mathrm{~m}$ depth. The tidal harmonic analysis and vertical displacements of water parcels showed the pattern characteristic of internal waves generated in the presence of stratification and rough bottom topography. Most likely, the main source of the internal tidal waves was the interaction of high tides typical for Hudson Bay with sill-like features located below the halocline in the narrow channel between the islands.

While the tidal-driven variability in temperature and salinity recorded by the mooring was large, the high stratification to the south of the Belcher Islands during winter restricted vertical mixing. Tidally driven vertical mixing appears to be insignificant as evidenced by the occurrences of double diffusive staircases. Upwelling-favourable storms can be another efficient mechanism of vertical mixing; however, during winter, the land-fast ice eliminates wind stress from the water column.

The analysis of satellite SAR data clearly showed that isolated solitary waves (ISWs) were present in the study region throughout the icefree season, with the first (and last) manifestations of internal solitary waves occurring in May (November). Analysis of Froude numbers from winter observations allows the possibility of ISW generation in winter but unfortunately the available winter measurements do not resolve high-frequency motion and therefore cannot be used to support nor refute this possibility. 


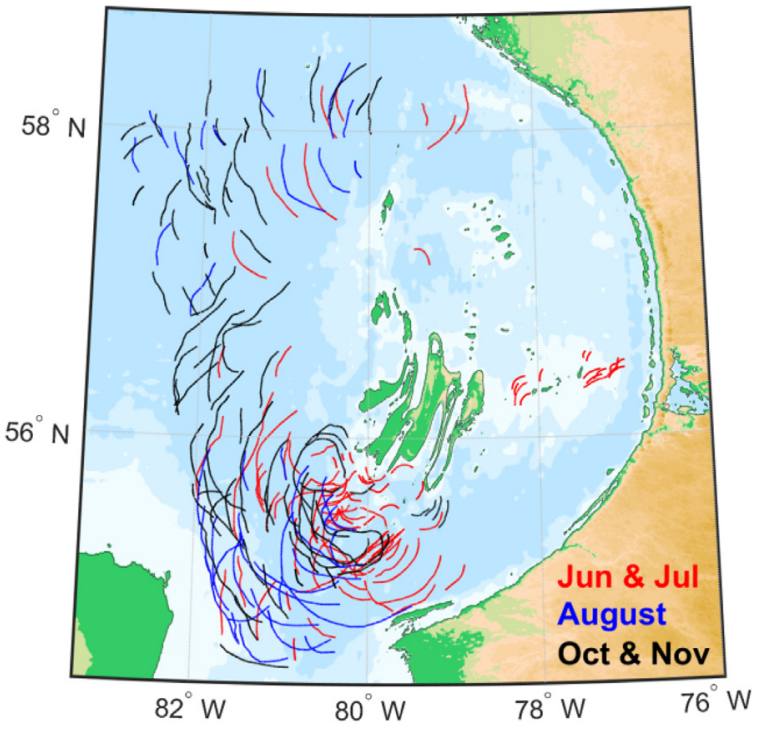

Fig. 12. Seasonal distribution of ISW locations in southeast Hudson Bay acquired between June and November of 2015-2017. (For interpretation of the references to color in this figure legend, the reader is referred to the web version of this article).

An overall impression of the manifestation of ISWs south of the Belcher Islands in SAR images (high radar contrasts and relatively large spatial scales) suggests that these features might be rather intensive internal waves as observed in some other Arctic regions (e.g. Sandven and Johannessen, 1987; Padman and Dillon, 1989; Czipott et al., 1991; Kozlov et al., 2014).

\section{Acknowledgements}

This study is an example of fruitful research that can be completed through cooperation between the scientific and indigenous communities in the Arctic. This research would not have been possible without the excellent support of the Arctic Eider Society and the Sanikiluaq Hunters and Trappers Association and in particular the skilled hunters and guides that took us out on the ice and coastal waters. As well, funding support from the Natural Sciences and Engineering Research Council (NSERC), Canada, Discovery Grant program, the ArcticNet Network of Centres of Excellence, Canada, and BaySys (Hudson Bay System Study), Canada, made field data collection and analysis possible. We also acknowledge funding support from the Nunavut General Monitoring Program to the Arctic Eider Society, Canada, and contributions from the Canada Excellence Research Chair (CERC), Canada, and Canada Research Chair (CRC), Canada, programs to support the University of Manitoba team. This manuscript is a contribution to the Arctic Science Partnership (ASP), Canada-Greenland-Denmark asp-net.org.

We acknowledge the use of imagery provided by services from the Information System (ESDIS, https://earthdata.nasa.gov) with funding provided by National Aeronautics and Space Administration (NASA), U.S.A.

We acknowledge the use of imagery provided by services from RADARSAT-2 Data and Products (CMacDonald, Dettwiler and Associates Ltd. (2009) - All Rights Reserved. RADARSAT is an official mark of the Canadian Space Agency. RADARSAT-2 data are available for a fee from the National Earth Observation Data Framework Catalog (https://neodf.nrcan.gc.ca).

We acknowledge the use of Sentinel imagery provided by services from the European Space Agency - ESA, European Union (https:// scihub.copernicus.eu).

Igor E. Kozlov acknowledges support from Russian Foundation for Basic Research (RFBR), Russia, Grant No. 16-35-60072 mol_a_dk.

\section{References}

Alford, M.H., 2003. Redistribution of energy available for ocean mixing by long-range propagation of internal waves. Nature 423, 159-162. (Nature Publishing Group.) (Online) (Available). 〈http://uml.idm.oclc.org/login?url=http://search.ebscohost. com/login. aspx direct $=$ true $\& d b=a 9 h \& A N=9700589 \&$ site $=$ ehost-live $\rangle$.

Chen, C., Gao, G., Qi, J., Proshutinsky, A., Beardsley, R.C., Kowalik, Z., Lin, H., Cowles, G., 2009. A new high-resolution unstructured grid finite volume Arctic ocean model (AO-FVCOM): an application for tidal studies. J. Geophys. Res. Ocean. 114. https:// doi.org/10.1029/2008JC004941.

Czipott, P.V., Levine, M.D., Paulson, C.A., Menemenlis, D., Farmer, D.M., Williams, R.G., 1991. Ice flexure forced by internal wave packets in the Arctic Ocean. Sci. (80-.). 254, 832-835. (American Association for the Advancement of Science.)(Online) (Available). 〈http://www.jstor.org/stable/2879653〉.

Déry, S.J., Hernández-Henríquez, M. a., Burford, J.E., Wood, E.F., 2009. Observational evidence of an intensifying hydrological cycle in northern Canada. Geophys. Res. Lett. 36, 1-5. https://doi.org/10.1029/2009GL038852.

Déry, S.J., Mlynowski, T.J., Hernández-Henríquez, M.A., Straneo, F., 2011. Interannual variability and interdecadal trends in Hudson Bay streamflow. J. Mar. Syst. 88, 341-351. https://doi.org/10.1016/j.jmarsys.2010.12.002.

Déry, S.J., Stieglitz, M., McKenna, E.C., Wood, E.F., 2005. Characteristics and trends of river discharge into Hudson, James, and Ungava Bays, 1964-2000. J. Clim. 18, 2540-2557. https://doi.org/10.1175/JCLI3440.1.

Dmitrenko, I.A., Kirillov, S.A., Bloshkina, E., Lenn, Y.D., 2012. Tide-induced vertical mixing in the Laptev Sea coastal polynya. J. Geophys. Res. 117. https://doi.org/10. 1029/2011jc006966.

Dmitrenko, I.A., Kirillov, S.A., Rysgaard, S., Barber, D.G., Babb, D.G., Pedersen, L.T., Koldunov, N.V., Boone, W., Crabeck, O., Mortensen, J., 2015. Polynya impacts on water properties in a Northeast Greenland Fiord. Estuar. Coast. Shelf Sci. 153, 10-17. https://doi.org/10.1016/j.ecss.2014.11.027.

Dmitrenko, I.A., Wegner, C., Kassens, H., Kirillov, S.A., Krumpen, T., Heinemann, G., Helbig, A., Schroder, D., Holemann, J.A., Klagge, T., Tyshko, K.P., Busche, T., 2010. Observations of supercooling and frazil ice formation in the Laptev Sea coastal polynya. J. Geophys. Res. 115. https://doi.org/10.1029/2009jc005798.

Dmitrenko, I., Hölemann, J., Kirillov, S., Berezovskaya, S., Ivanova, D., Eicken, H., Kassens, H., 2002. The impact of sea ice on the periodic shallow water dynamics in the Laptev Sea (Siberian Arctic). pp. 77-83 in Ice in the Environment In: Proceedings of the 16th IAHR International Symposium on Ice, Dunedin, New Zealand.

Eastwood, R.A., 2018. Physical Properties and Isotopic Characteristics of the Winter Water Column and Landfast Sea-ice Surrounding the Belcher Islands, Southeast Hudson Bay. University of Manitoba.

Egbert, G.D., Ray, R.D., 2000. Significant dissipation of tidal energy in the deep ocean inferred from satellite altimeter data (Online) (Available). Nature 405, 775-778. https://doi.org/10.1038/35015531.

Farmer, D.M., Freeland, H.J., 1983. The physical oceanography of Fjords. Prog. Oceanogr. $12,147-220$.

Ferland, J., Gosselin, M., Starr, M., 2011. Environmental control of summer primary production in the Hudson Bay system: the role of stratification. J. Mar. Syst. 88, 385-400. https://doi.org/10.1016/j.jmarsys.2011.03.015.

Freeman, N.G., Murty, T.S., 1976. Numerical modeling of tides in Hudson Bay. J. Fish. Res. Board Can. 33, 2345-2361. https://doi.org/10.1139/f76-282.

Garrett, C., 2003. Internal tides and ocean mixing. Science 301, 1858-1859. https://doi. org/10.1126/science.1090002.

Garrett, C., Kunze, E., 2007. Internal tide generation in the deep ocean. Annu. Rev. Fluid Mech. 39, 57-87. https://doi.org/10.1146/annurev.fluid.39.050905.110227.

Granskog, M.A., Kaartokallio, H., Kuosa, H., 2009a. Sea ice in non-polar regions. In: Thomas, D.N., Dieckmann, G.S. (Eds.), Sea Ice. Wiley-Blackwell, Oxford, UK, pp. 531-577. https://doi.org/10.1002/9781444317145.ch14.

Granskog, M.A., Kuzyk, Z.Z.A., Azetsu-Scott, K., Macdonald, R.W., 2011. Distributions of runoff, sea-ice melt and brine using $\delta 180$ and salinity data - a new view on freshwater cycling in hudson bay. J. Mar. Syst. 88, 362-374. https://doi.org/10.1016/j. jmarsys.2011.03.011.

Granskog, M.A., Macdonald, R.W., Kuzyk, Z.Z.A., Senneville, S., Mundy, C.-J., Barber, D.G., Stern, G.A., Saucier, F., 2009b. Coastal conduit in southwestern Hudson Bay (Canada) in summer: rapid transit of freshwater and significant loss of colored dissolved organic matter. J. Geophys. Res. 114, C08012. https://doi.org/10.1029/ 2009JC005270.

Groeskamp, S., Nauw, J.J., Maas, L.R.M., 2011. Observations of estuarine circulation and solitary internal waves in a highly energetic tidal channel. Ocean Dyn. 61, 1767-1782. https://doi.org/10.1007/s10236-011-0455-y.

Guthrie, J.D., Morison, J.H., Fer, I., 2013. Revisiting internal waves and mixing in the Arctic Ocean. J. Geophys. Res. Ocean. 118, 3966-3977. https://doi.org/10.1002/ jgrc. 20294.

Haury, L.R., Briscoe, M.G., Orr, M.H., 1979. Tidally generated internal wave packets in Massachusetts Bay (Nature Publishing Group.)(Online) (Available). Nature 278, 312. https://doi.org/10.1038/278312a0.

Heath, J.P., Gilchrist, H.G., Ydenberg, R.C., 2006. Regulation of stroke pattern and swim speed across a range of current velocities: diving by common eiders wintering in polynyas in the Canadian Arctic. J. Exp. Biol. 209, 3974-3983. https://doi.org/10. 1242/jeb.02482.

Hochheim, K.P., Barber, D.G., 2014. An update on the ice climatology of the Hudson Bay system. Arct., Antarct. Alp. Res. 46, 66-83. https://doi.org/10.1657/1938-4246-46. 1.66. (Institute of Arctic and Alpine Research)(INSTAAR)(, University of Colorado).

Jackson, C.R., Da Silva, J.C.B., Jeans, G., 2012. The generation of nonlinear internal waves. Oceanography 25, 108-123. https://doi.org/10.5670/oceanog.2012.46. 
Jackson, G.D., 1960. Belcher Islands, Northwest Territories. Geological Survey of Canada Paper 60-20. Department of Mines and Technical Surveys, Ottawa. 〈https://doi.org/ 10.4095/101205>.

Kirillov, S.A., Dmitrenko, I.A., Hölemann, J.A., Kassens, H., Bloshkina, E., 2013. The penetrative mixing in the Laptev Sea coastal polynya pycnocline layer. Cont. Shelf Res. 63, 34-42. https://doi.org/10.1016/j.csr.2013.04.040.

Kirillov, S., Dmitrenko, I., Rysgaard, S., Babb, D., Pedersen, L.T., Ehn, J., Bendtsen, J., Barber, D., 2017. Storm-induced water dynamics and thermohaline structure at the tidewater Flade Isblink Glacier outlet to the Wandel Sea (NE Greenland). Ocean Sci. Discuss. 13, 947-959. https://doi.org/10.5194/os-13-947-2017.

Kozlov, I., Romanenkov, D., Zimin, A., Chapron, B., 2014. SAR observing large-scale nonlinear internal waves in the White Sea. Remote Sens. Environ. 147, 99-107. https://doi.org/10.1016/j.rse.2014.02.017.

Kozlov, I.E., Kudryavtsev, V.N., Zubkova, E.V., Zimin, A.V., Chapron, B., 2015 Characteristics of short-period internal waves in the Kara Sea inferred from satellite SAR data. Izv. Atmos. Ocean. Phys. 51, 1073-1087. https://doi.org/10.1134/ S0001433815090121.

Kozlov, I.E., Zubkova, E.V., Kudryavtsev, V.N., 2017. Internal solitary waves in the Laptev Sea: first results of spaceborne SAR observations. IEEE Geosci. Remote Sens. Lett. PP, 1-5. https://doi.org/10.1109/LGRS.2017.2749681.

Landy, J.C., Ehn, J.K., Babb, D.G., Thériault, N., Barber, D.G., 2017. Sea ice thickness in the eastern Canadian Arctic: Hudson Bay complex \& Baffin Bay. Remote Sens. Environ. 200, 281-294. https://doi.org/10.1016/j.rse.2017.08.019.

(St)Laurent, L., Stringer, S., Garrett, C., Perrault-Joncas, D., 2003. The generation of internal tides at abrupt topography. Deep Sea Res. Part I Oceanogr. Res. Pap. 50, 987-1003. https://doi.org/10.1016/S0967-0637(03)00096-7.

Lim, J.S., 1990. Two-Dimensional Signal and Image Processing. Prentice Hall, Englewood Cliffs, NJ.

Luneva, M.V., Aksenov, Y., Harle, J.D., Holt, J.T., 2015. The effects of tides on the water mass mixing and sea ice in the Arctic Ocean. J. Geophys. Res. Ocean. 120 6669-6699. https://doi.org/10.1002/2014JC010310.

Macdonald, R.W., Kuzyk, Z.Z. a., 2011. The Hudson Bay system: a northern inland sea in transition. J. Mar. Syst. 88, 337-340. https://doi.org/10.1016/j.jmarsys.2011.06. 003.

Marchenko, A.V., Morozov, E.G., Muzylev, S.V., Shestov, A.S., 2010. Interaction of short internal waves with the ice cover in an Arctic Fjord. Oceanology 50, 18-27. https:// doi.org/10.1134/S0001437010010029.

Maxworthy, T., 1979. A note on the internal solitary waves produced by tidal flow over a three-dimensional ridge. J. Geophys. Res. 84, 338. https://doi.org/10.1029/ JC084iC01p00338.

Miranda, N., Meadows, P.J., 2015. Radiometric Calibration of S-1 Level-1 Products Generated by the S-1 IPF. Technical Note ESA-EOPG-CSCOP-TN-0002. European Space Agency.

Morozov, E.G., Kozlov, I.E., Shchuka, S.A., Frey, D.I., 2017. Internal tide in the Kara Gates Strait. Oceanology 57, 8-18. https://doi.org/10.1134/S0001437017010106.

Morozov, E.G., Marchenko, A.V., 2012. Short-period internal waves in an arctic Fjord (Spitsbergen). Izv. Atmos. Ocean. Phys. 48, 401-408. https://doi.org/10.1134/ S0001433812040123.

Morozov, E.G., Paka, V.T., Bakhanov, V.V., 2008. Strong internal tides in the Kara Gates Strait. Geophys. Res. Lett. 35, L16603. https://doi.org/10.1029/2008GL033804.

Morozov, E.G., Pisarev, S.V., 2002. Internal tides at the Arctic latitudes (numerical experiments). Oceanology 42, 153-161.

Nash, J.D., Moum, J.N., 2005. River plumes as a source of large-amplitude internal waves in the coastal ocean (Nature Publishing Group). Nature 437, 400-403. https://doi. org/10.1038/nature03936.

Padman, L., Dillon, T.M., 1989. Thermal microstructure and internal waves in the Canada Basin diffusive staircase. Deep Sea Res. Part A Oceanogr. Res. Pap. 36, 531-542. https://doi.org/10.1016/0198-0149(89)90004-6.

Parsmar, R., Stigebrandt, A., 1997. Observed damping of barotropic seiches through baroclinic wave drag in the Gullmar Fjord. J. Phys. Oceanogr. 27, 849-857. https:// doi.org/10.1175/1520-0485(1997)027<0849:ODOBST > 2.0.CO;2.

Pawlowicz, R., Beardsley, B., Lentz, S., 2002. Classical tidal harmonic analysis including error estimates in MATLAB using T_TIDE. Comput. Geosci. 28, 929-937. https://doi.
org/10.1016/S0098-3004(02)00013-4.

Pelletier, B.R., 1968. Submarine physiography, bottom sediments, and models of sediment transport in Hudson Bay. In: Hood, P. (Ed.), Earth Science Symposium on Hudson Bay. Geological Survey of Canada, Ottawa, pp. 100-135. https://doi.org/10. 4095/102950.

Petrusevich, V., Dmitrenko, I.A., Kirillov, S.A., Rysgaard, S., Falk-Petersen, S., Barber, D.G., Boone, W., Ehn, J.K., 2016. Wintertime water dynamics and moonlight disruption of the acoustic backscatter diurnal signal in an ice-covered Northeast Greenland fjord. J. Geophys. Res. Ocean. 121, 4804-4818. https://doi.org/10.1002/ 2016JC011703.

Phillips, O.M., 1977. The Dynamics of the Upper Ocean, 2nd edition. Cambridge University Press, Cambridge-London-New York-Melbourne (Online) (Available). $\langle$ https://books.google.ca/books?id = vJZfOgAACAAJ〉.

Prinsenberg, S.J., 1986a. The circulation pattern and current structure of Hudson Bay. In: Martini, I.P. (Ed.), Canadian Inland Seas. Elsevier Science, pp. 187-204. https://doi. org/10.1016/S0422-9894(08)70903-6.

Prinsenberg, S.J., 1986b. Salinity and temperature distributions of Hudson Bay and James Bay. In: Martini, I.P. (Ed.), Canadian Inland Seas. Elsevier Science, pp. 163-186. https://doi.org/10.1016/S0422-9894(08)70902-4.

Prinsenberg, S.J., 1987. Seasonal current variations observed in western Hudson Bay. J. Geophys. Res. Ocean. 92, 756-766. https://doi.org/10.1029/JC092iC10p10756.

Prinsenberg, S.J., Freeman, N.G., 1986. Tidal heights and currents in Hudson Bay and James Bay. In: Martini, I.P. (Ed.), Canadian Inland Seas. Elsevier Science, pp. 205-216. https://doi.org/10.1016/S0422-9894(08)70904-8.

Rippeth, T.P., Vlasenko, V., Stashchuk, N., Scannell, B.D., Green, J.A.M., Lincoln, B.J., Bacon, S., 2017. Tidal Conversion and Mixing Poleward of the Critical Latitude (an Arctic case study). Geophys. Res. Lett. 44, 12,349-12,357. https://doi.org/10.1002/ 2017GL075310.

Robinson, I.S., da Silva, J., 2010. Internal waves. pp. 453-483 in Discovering the Ocean from Space: The unique applications of satellite oceanography. Springer Berlin Heidelberg, Berlin, Heidelberg. doi:10.1007/978-3-540-68322-3 12.

Roquet, F., Madec, G., McDougall, T.J., Barker, P.M., 2015. Accurate polynomial expressions for the density and specific volume of seawater using the TEOS-10 standard. Ocean Model. 90, 29-43. https://doi.org/10.1016/j.ocemod.2015.04.002.

Sandven, S., Johannessen, O.M., 1987. High-frequency internal wave observations in the marginal ice zone. J. Geophys. Res. Ocean. 92, 6911-6920. https://doi.org/10.1029/ JC092iC07p06911.

Saucier, F.J., Senneville, S., Prinsenberg, S., Roy, F., Smith, G., Gachon, P., Caya, D., Laprise, R., 2004. Modelling the sea ice-ocean seasonal cycle in Hudson Bay, Foxe Basin and Hudson Strait, Canada. Clim. Dyn. 23, 303-326. https://doi.org/10.1007/ s00382-004-0445-6.

St-Laurent, P., Saucier, F.J., Dumais, J.F., 2008. On the modification of tides in a seasonally ice-covered sea. J. Geophys. Res. Ocean. 113, 1-11. https://doi.org/10.1029/ 2007JC004614.

Staalstrøm, A., Aas, E., Liljebladh, B., 2012. Propagation and dissipation of internal tides in the Oslofjord. Ocean Sci. 8, 525-543. https://doi.org/10.5194/os-8-525-2012.

Støylen, E., Fer, I., 2014. Tidally induced internal motion in an Arctic fjord. Nonlinear Process. Geophys. 21, 87-100. https://doi.org/10.5194/npg-21-87-2014.

Støylen, E., Weber, J.E.H., 2010. Mass transport induced by internal Kelvin waves beneath shore-fast ice. J. Geophys. Res. Ocean. 115, C03022. https://doi.org/10.1029/ 2009JC005298.

Svendsen, H., Beszczynska-Møller, A., Hagen, J.O., Lefauconnier, B., Tverberg, V., Gerland, S., Ørbæk, J.B., Bischof, K., Papucci, C., Zajaczkowski, M., Azzolini, R. Bruland, O., Wiencke, C., Winther, J.-G., Dallmann, W., 2002. The physical environment of Kongsfjorden - Krossfjorden, an Arctic fjord system in Svalbard. Polar Res. 21, 133-166. https://doi.org/10.1111/j.1751-8369.2002.tb00072.x.

Wang, J., Mysak, L.A., Ingram, R.G., 1994. A three-dimensional numerical simulation of Hudson Bay summer ocean circulation: topographic gyres, separations, and coastal jets. J. Phys. Oceanogr. 24, 2496-2514. https://doi.org/10.1175/1520-0485(1994) 024 < 2496:ATDNSO > 2.0.CO;2. (American Meteorological Society).

Webb, D.J., 2014. On the tides and resonances of Hudson Bay and Hudson Strait. Ocean Sci. 10, 411-426. https://doi.org/10.5194/os-10-411-2014. 